\title{
真空中での光触媒によるコンタミネーション防止実験*1 \\ Study on Molecular Contamination Prevention by Using Photocatalysts under Vacuum Conditions
}

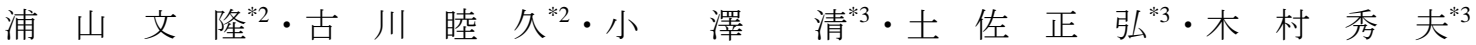 \\ Fumitaka Urayama, Mutsuhisa Furukawa, Kiyoshi Ozawa, Masahiro Tosa and Hideo Kimura
}

Key Words: Molecular Contamination, Photocatalyst, Vacuum, Ultraviolet

\begin{abstract}
To better understand the characteristics for preventing organic contaminants from accumulating on the critical surfaces of spacecraft, we studied on the effective prevention of molecular contaminants by using photocatalysts under ultraviolet irradiation and vacuum conditions. Squalene, tetra-methyl tetra-phenyl tri-siloxane, oleamide and diethylhexyl phthalate were used as model contaminants. $\mathrm{TiO}_{2}$ particles and $\mathrm{TiO}_{2}$-coated substrates were used as photocatalysts. $\mathrm{TiO}_{2}$ was effective in weight losses of all organics under the conditions. Transmittance of the $\mathrm{TiO}_{2}$-coated substrates increased depending on UV irradiation time.
\end{abstract}

1. は じめ に

宇宙環境下において宇宙機用材料等から放出される分子 状コンタミネーションは, 宇宙機表面へ付着し, 熱制御材 の太陽光吸収率の増加や光学系の反射率・透過率の低下を 引き起こし，ミッションへ悪影響を及ぼすことが知られて いる ${ }^{1,2)}$.

軌道上でのコンタミネーション付着物の除去方法として, 例えばハッブル宇宙望遠鏡や我が国の太陽観測衛星「ひの で」では光学系を室温より若干高い温度で付着物を昇華さ せる3゙などに見られるように, 現時点で実用化されている手 法は昇温のみである。 また, 原子状酸素による付着物の浸 食現象による除去も期待されるが，原子状酸素フルエンス の微小な低軌道宇宙機のウェイク側や静止軌道衛星, 探査 衛星, 月面では無効である。 そこで, 我々は宇宙に豊富に ある太陽紫外線を有効活用し, 特別な機構を必要としない 光触媒によるパッシブなコンタミネーション防止に着目し, 実験研究を進めている. 半導体である光触媒に紫外線(UV) が当たると, 価電子帯の電子が伝導帯へと励起し, 電子と 正孔が生じる. 酸素と水がそれぞれ電子と正孔に反応し, 活性酸素及びヒドロキシラジカルが有機分子を酸化分解す ると言われている4).これが光触媒によるコンタミネーショ ン防止のメカニズムである。一方, 自然の宇宙環境には水 は存在しないが, 宇宙機自体の材料からは有機物のほかに 水も放出されている. 我が国の Space Flyer Unit (SFU)では 打上げから約 3 カ月間まで質量分析器により水が検出され 続けており ${ }^{5)}$ ，宇宙機自体が水の供給源となる．日照時に宇 宙機の温度が上がると有機物と一緒に水も放出される傾向

\footnotetext{
${ }^{1}$ C2007 日本航空宇宙学会

平成 19 年 7 月 31 日原稿受理

*2国立大学法人 長崎大学大学院

*3 独立行政法人 物質・材料研究機構
}

があり, 光触媒によるタイムリーなコンタミネーション防 止が期待できる.ただし，アウトガス放出レートは時間の 経過とともに減少していく特徴がある ${ }^{6,7}$ ため, アウトガス 放出レートが高いミッション初期のみでもコンタミネーシ ヨンの付着防止を図ることにより, 結果的にミッションの 長寿命化につながると期待される。 また, 国際宇宙ステー ションなどの有人宇宙機では，船内の大気から収集した凝 縮水を船外一定期的に排水するため ${ }^{8)}$, 光触媒にとっては貴 重なリソースである. 光触媒には有機物の酸化分解効果の ほか，超親水性という特長もあわせ持ち ${ }^{9)}$, 水が光触媒の表 面に吸着した状態でアウトガスの到来を待ち受けることに なる.

これまでの研究では，コンタミネーションモデル物質と して炭化水素のアタクティック・ポリスチレン (MW ca $100,000)$ とスクアレン $\left(\mathrm{C}_{30} \mathrm{H}_{50}, \mathrm{MW} 411\right)$, 光触媒として二 酸化チタン $\mathrm{TiO}_{2}$ 粒子と水酸化チタン $\mathrm{Ti}(\mathrm{OH}) \mathrm{x}$ 粒子を用いて 真空中で UV 照射実験を行った。その結果，真空中におい ても $\mathrm{TiO}_{2}$ と $\mathrm{Ti}(\mathrm{OH}) \mathrm{x}$ の混合物は, 低分子であるスクアレン の重量減少に有効であることを見出した ${ }^{10)}$.

本稿では，「ひので」使用材料から放出されるアウトガス 成分などをモデル物質として，これら光触媒粒子によるモ デル物質の重量減少の効果を確認するとともに, $\mathrm{TiO}_{2}$ 薄膜 によるコンタミネーション防止効果として可視光透過スペ クトル特性を分析し評価した結果をまとめている。

\section{2. 光触媒の合成}

真空中での光触媒によるモデル物質の重量変化を電子天 秤で検出し易くするため, 光触媒薄膜よりも有機物との接 触面積が大きくなる粒子を実験に用いた. 光触媒の種類と しては, 日本アエロジルの $\mathrm{TiO}_{2}$ 超微粒子 P25 (平均粒径約 $21 \mathrm{~nm})$, 三塩化チタンとアンモニア水から $\mathrm{Ti}(\mathrm{OH}) \mathrm{x}$ 粒子 $(\mathrm{x}=$ 
3.2)を合成し, $250^{\circ} \mathrm{Cで} 24$ 時間熱処理したものを用いた ${ }^{10)}$. 後者は, 熱処理後に乳鉢ですり潰したものの視認できる程 度の粒径(おおよそ $100 \mu \mathrm{m}$ 以下)であった. 第 1 図に示す粉 末 $\mathrm{X}$ 線回折(XRD)測定結果からアナターゼ型 $\mathrm{TiO}_{2}$ のピーク が見られるため, 合成・熱処理を行った粒子はアナターゼ 型 $\mathrm{TiO}_{2}$ とアモルファスの $\mathrm{Ti}(\mathrm{OH}) \mathrm{x}$ の混合物 ${ }^{11)}$ と推測される.

次に, ゾル・ゲル法により $\mathrm{CaF}_{2}$ 基板に $\mathrm{TiO}_{2}$ 薄膜をコー ティングした．原料にはチタン酸イソプロピル(TTIP), 2-

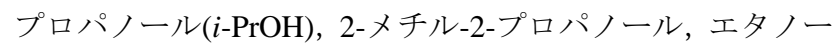
ル $(\mathrm{EtOH})$, ジェタノールアミン(DEA)を用いた。 TTIP を $i-\mathrm{PrOH}$ に溶解し, 窒素雰囲気下で DEA を添加した後に室 温で 2 時間攪拌した ${ }^{12)}$. この溶液を用いてスピンコート法 (2500 rpm, 30 秒間)により $7 \mathrm{~mm}$ 四方の $\mathrm{CaF}_{2}$ 基板(UV グレ ード)及び $\mathrm{SiO}_{2}$ 基板にコーティングし, $100^{\circ} \mathrm{C}$ で 20 時間乾燥, $500^{\circ} \mathrm{C}$ で 1 時間の結晶化熱処理を行った. 代表的な宇宙機構 造部材である Al 合金 A2024 に 2 滴コーティングしたとき は SEM 断面観察より $200 \mu \mathrm{m}$ 厚であった. そのときの TTIP 濃度を半分, 1 滴としたため, 厚さは $50 \mu \mathrm{m}$ 程度と推測さ れる. XRD 測定結果からアナターゼ型のピークが観察され た. $\mathrm{CaF}_{2}$ 基板にコーティングした $\mathrm{TiO}_{2}$ 薄膜サンプルの紫 外・可視(UV/VIS)透過率スペクトルを第 2 図に示す. 波長 約 $340 \mathrm{~nm}$ 以下に $\mathrm{TiO}_{2}$ 薄膜による強い吸収が見られた.

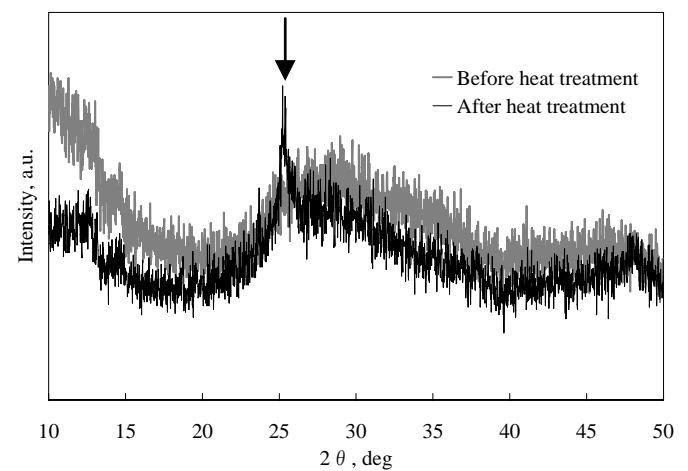

第 1 図 $\mathrm{Ti}(\mathrm{OH}) \mathrm{X}$ 粒子の熱処理前後の XRD 測定結果

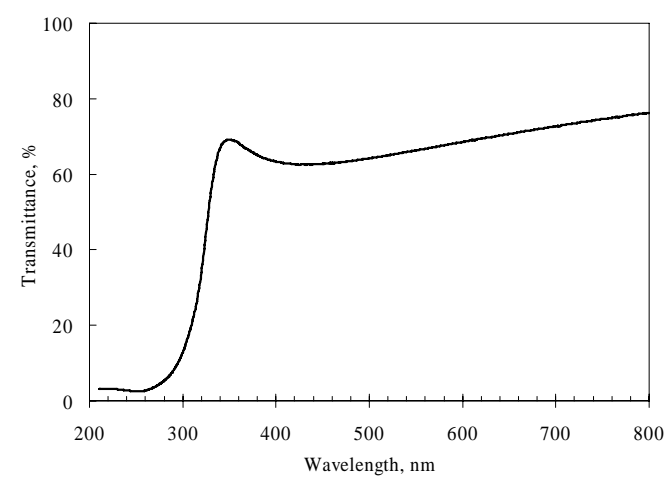

第 2 図 $\mathrm{TiO}_{2}$ 薄膜/ $/ \mathrm{CaF}_{2}$ 基板の UV/VIS 透過率スペクトル

\section{3. 実験}

UV 照射実験装置の概観を第 3 図に示す. 到達真空度は $10^{-4} \mathrm{~Pa}$ である。光源には三栄電機製作所の $200 \mathrm{~W}$ 水銀キセ ノン光源 UVF-203S を用い, 波長 245 475 nm, 中心波長
$365 \mathrm{~nm}$ の紫外・可視光を照射することができる. UV 強度 測定には波長 290〜390 nm を範囲とするカスタムの UV-340 を用い, サンプル位置での UV 強度を適宜測定した。

コンタミネーションモデル物質にはスクアレンのほか,

「ひので」使用材料のアウトガス成分であるオレアミド $\left(\mathrm{C}_{18} \mathrm{H}_{35} \mathrm{NO}, \mathrm{MW} 281\right)$, フタル酸ジェチルヘキシル(DEHP, $\left.\mathrm{C}_{24} \mathrm{H}_{38} \mathrm{O}_{4}, \mathrm{MW} 391\right)$, テトラメチル・テトラフェニル・トリシ ロキサン(MPS, $\mathrm{C}_{28} \mathrm{H}_{32} \mathrm{O}_{2} \mathrm{Si}_{3}$, MW 485)を用いた. これらの化 学構造を第 4 図に示す.

光触媒粒子を用いたサンプルは次のように作成した. 光 触媒粒子を $\mathrm{EtOH}$ に懸濁しシャーレまたは $\mathrm{CaF}_{2}$ 基板に滴下 後 $\mathrm{EtOH}$ を蒸発させ, その後, 常温で液体のスクアレンま たは MPS を滴下した. 常温で固体のオレアミドについては, EtOH に溶解しシャーレに滴下後 EtOH を蒸発させた。 これ らの方法により, 光触媒粒子と有機物の重量比をある程度 コントロールすることができる. 一方, $\mathrm{TiO}_{2}$ 薄膜に関して は, 1〜2 mg のオレアミド, DEHP を付着させた.

第 3 図に示すように真空中でサンプルにUV を照射し, UV 照射前後のサンプルの重量を電子天秤で測定した. 光触 媒粒子を用いたサンプルの作成に当たっては，秤量時にお ける光触媒の吸湿の影響を少なくするため, 光触媒の重量 パーセントが極力少なくなるように調製した。そのほか, 島津製作所の MPS-2400による基板サンプルのUV/VIS 透過 率スペクトル測定, 日本分光の FT/IR-8000 による赤外(IR) 透過スペクトル測定を行った。

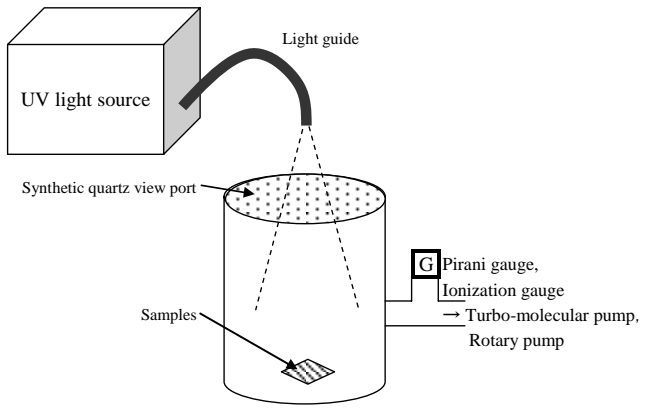

第 3 図 UV 照射実験装置の概観
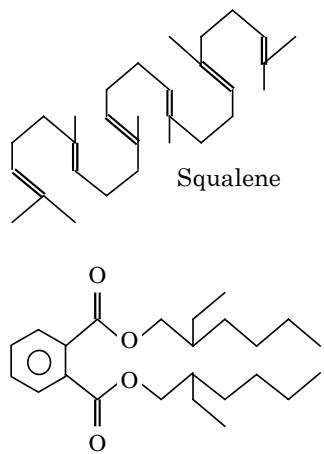

Diethylhexyl phthalate (DEHP)

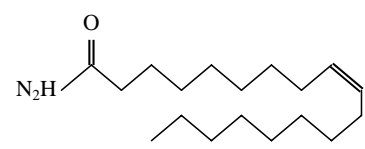

Oleamide

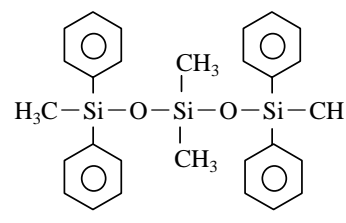

Tetra-methyl tetra-phenyl tri-siloxane (MPS)
第 4 図 コンタミネーションモデル物質の化学構造 


\section{4. 結 果と考 察}

4.1 光触媒微粒子 まず, 前報 ${ }^{10)}$ で使用したスクアレン を用いて, UV 照射時間と光触媒粒子による重量減少効果の 関係を調べた。真空中 UV 照射によるスクアレンの重量減 少率を第 5 図に示寸，第 5 図の Equivalent Sun Days (ESD) は，波長 290〜390 nm での UV 強度と照射時間から換算し たエアマスゼロでの等価太陽照射日数である．ここでは， スクアレンの初期重量を $20 〜 40 \mathrm{mg}$ とし, 光触媒を 4〜18 wt\%とした．TG-DTA より $\mathrm{TiO}_{2} / \mathrm{Ti}(\mathrm{OH}) \mathrm{x}$ 粒子は $10 \mathrm{wt} \%$ 程度 10), P25 超微粒子は $2 \mathrm{wt} \%$ 弱の保水力を有したため, スクア レンと $\mathrm{TiO}_{2} / \mathrm{Ti}(\mathrm{OH}) \mathrm{x}$ の混合物に対する大気中水分の影響は 最大でも $1.8 \mathrm{wt} \%$ と推測される. UV 照射時間に伴い, どの サンプルにおいても重量減少率が高くなる傾向があった. また, スクアレン単体よりも, 光触媒粒子を添加したサン プルの重量減少率のほうが高くなった。重量減少の要因と してスクアレン自体の蒸発もあるが, 真空中 UV 非照射下 でのスクアレンの重量減少率は 39 時間で $0.2 \mathrm{wt} \%$ に満た なかった。また，第 6 図に示すように, UV 照射前のスクア レン(二重結合数 6)には波長約 $300 \mathrm{~nm}$ 以下に吸収があるた め, 本実験に使用した UV 光源により光化学反応を起こし 得る必要条件を満たしており, かつ, UV 照射後のスクアレ ンでは波長約 $350 \mathrm{~nm}$ 以下での UV 吸収が増加した。したが って, 第 5 図に示すスクアレン単体の重量減少は蒸発より

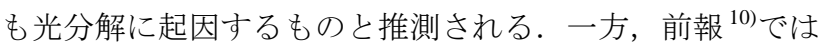
$\mathrm{TiO}_{2}$ と $\mathrm{Ti}(\mathrm{OH}) \mathrm{x}$ の組合せがスクアレンの重量減少に効果的 であると報告したが, 今回の実験により $\mathrm{TiO}_{2}(\mathrm{P} 25)$ のの場 合でも効果があることが判った。第 7 図に UV 照射前後の スクアレンの FTIR 透過スペクトルを示す.いずれのサンプ ルにおいてもそれぞれ 1732, $1720 \mathrm{~cm}^{-1}$ にカルボニル基 R-CHO, R-CO-R'による吸収 ${ }^{13)}$ が見られた。 大気中でスクア レンに UV を照射するとこれらカルボニル基が生じたとの 報告もある ${ }^{14)}$. 真空チャンバからサンプルを取り出した後 に FTIR 分析を行っているため, 大気曝露による酸化の影響 もあると考えられるが，P25 を添加したサンプルのほうが 若干ながら酸化が進んでいる傾向が見られ, 真空チャンバ 中でも酸化が起きていると推測される. 真空中で酸化が起 こるためには酸素や水が必要であるが, 前述の TG-DTA デ 一タから $\mathrm{TiO}_{2} / \mathrm{Ti}(\mathrm{OH}) \mathrm{x}$ 自体が有機物の分解に関与する水の 供給源になり得ると考えられる. $\mathrm{P} 25$ は $\mathrm{TiO}_{2} / \mathrm{Ti}(\mathrm{OH}) \mathrm{x} よ り$ も保水力に劣るが, 第 5 図に示すように P25 を添加したサ ンプルの重量減少率は $\mathrm{TiO}_{2} / \mathrm{Ti}(\mathrm{OH}) \mathrm{x}$ よりも高くなった。 こ れは, P25 超微粒子(比表面積約 $50 \mathrm{~m}^{2} / \mathrm{g}$ ) とスクアレンの接 触面積が $\mathrm{TiO}_{2} / \mathrm{Ti}(\mathrm{OH}) \mathrm{x}$ 粒子(比表面積の概算值 $0.01 \mathrm{~m}^{2} / \mathrm{g}$ )の 場合よりも大きく，化学反応がより生じやすい条件であっ た可能性がある.そのほか, 酸素が関与している可能性も ある、酸素の起源については諸説あり, 超高真空下でも残
留酸素分子が関与する説 $\left.{ }^{15}\right), \mathrm{TiO}_{2}$ 結晶表面近傍の格子酸素 が抜けて関与する説 ${ }^{16)}, \mathrm{TiO}_{2}$ 表面の水酸基が関与する説 ${ }^{17)}$, がある．酸素が関与するとしても光触媒粒子の比表面積が 重要なファクタと考えられる。我々が実施した実験では重 量減少の主要因を特定することはできなかったが， $10^{-4} \mathrm{~Pa}$ 程度の真空中でも光触媒によるスクアレンの重量減少効果 があったと言える。

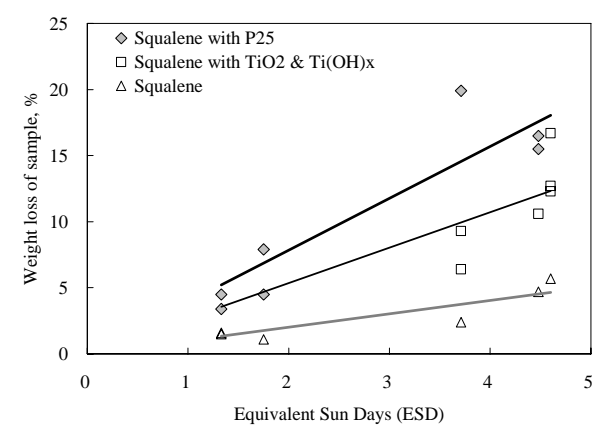

第 5 図 UV 照射によるスクアレンの重量減少率

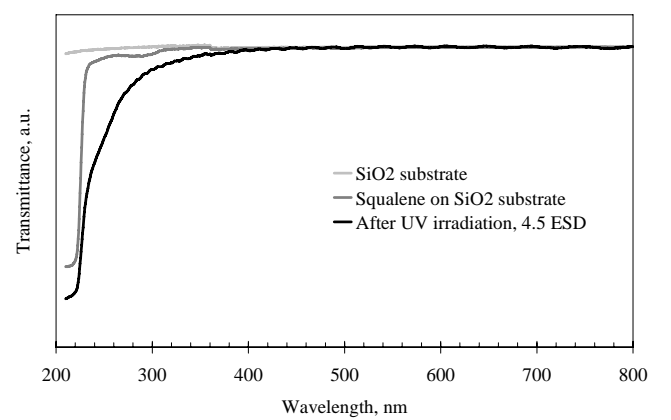

第 6 図 UV 照射前後のスクアレンの UV/VIS 透過スペクトル

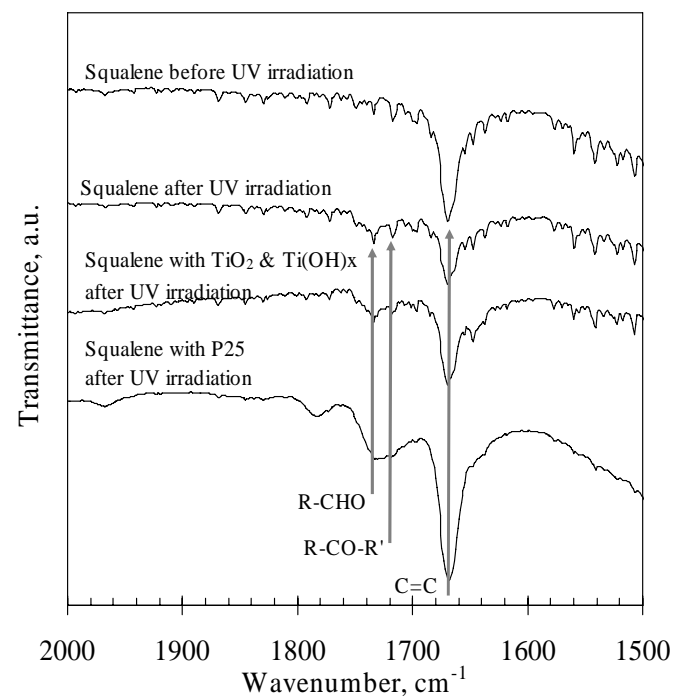

第 7 図 UV 照射前後のスクアレンの FTIR 透過スペクトル

次に，「ひので」に使用されている材料からのアウトガス 成分である MPS 及びオレアミドを対象として, 光触媒粒子 を用いて実験を行った．MPS 及びオレアミドの重量減少に 
対する光触媒粒子の効果をそれぞれ第 8, 9 図に示す. MPS の初期重量は $30 \mathrm{mg}$ 前後, オレアミドは $80 \mathrm{mg}$ 前後であっ た. 第 10,11 図には UV 照射前後の MPS 及びオレアミドの UV/VIS 透過スペクトルをそれぞれ示す. スクアレンと同様, 4 つのフェニル基を有する MPS, 1 つのカルボニル基と 1 つの二重結合を有するオレアミドにも UV 光源波長域に吸 収があり, 第 8, 9 図より真空中 UV 非照射下での蒸発量も 比較的少なかった. また, 第 10,11 図より, 波長 $300 \mathrm{~nm}$ 以 上で真空中 UV 照射後の吸収が増加傾向にあった。したが って, MPS, オレアミド単体の重量減少は蒸発というより も光化学反応に起因すると考えられる.

MPS に関しては, 波長 $253.7 \mathrm{~nm}$ のUVを照射すると, $\mathrm{H}_{2}$ と $\mathrm{CH}_{4}$ が脱離するとの報告がある ${ }^{18)}$. 実験に使用した UV 光源の最短波長は $245 \mathrm{~nm}$ であり, $5 \mathrm{eV}$ のエネルギーがある. MPS 中の Si-O, Si-Phenyl (Ph), C-H, Si-CH C $_{3}$ 結合エネルギ 一はそれぞれ 8.3, 5.8, 4.5-4.8, 3.1 eV とされており ${ }^{19,20)}, \mathrm{C}-\mathrm{H}$, $\mathrm{Si}-\mathrm{CH}_{3}$ 結合の切断が可能となる. UV により切断された $\cdot \mathrm{H}, \cdot \mathrm{CH}_{3}$ がそれぞれ再結合し, $\mathrm{H}_{2}, \mathrm{CH}_{4}$ が脱離すると推測 される. このため, 選択的な MPS の化学結合の切断が予想 されたが, FTIR透過スペクトルではそのような傾向は示さ れなかった. 重量減少に関しては, $\mathrm{TiO}_{2} / \mathrm{Ti}(\mathrm{OH}) \mathrm{x}$ 粒子の顕 著な効果は見られなかった。 これは, 光触媒粒子による UV 遮蔽効果が現れ, MPS 自体の光分解を阻害していた可能性 がある ${ }^{10)}$. 一方, P25 超微粒子に関してはスクアレンと同様 に重量減少効果が見られた。

オレアミドに関しては, スクアレンや MPS に比べて重量 減少率が小さかった。 スクアレン, MPS は標準状態で透明 な液体であり，オレアミドは白い固体である.オレアミド をホットプレートで $100^{\circ} \mathrm{C}$ 近くに加熱すると透明な液体に なった，室温の真空チャンバ内ではオレアミドは白いまま の状態であった.このことから, オレアミドは真空中でも 室温では固体と推測される. 液体の有機物と比べ, UVによ り固体の有機物にラジカルが生じても拡散して他のラジカ ルに会合し難く, 元の状態に戻り易いと考えられる.した がって, スクアレンや MPS に比べてオレアミドのラジカル と活性酸素, ヒドロキシラジカル, あるいはオレアミドの ラジカル同士が会合し難く, 重量減少が進行し難い可能性 がある。

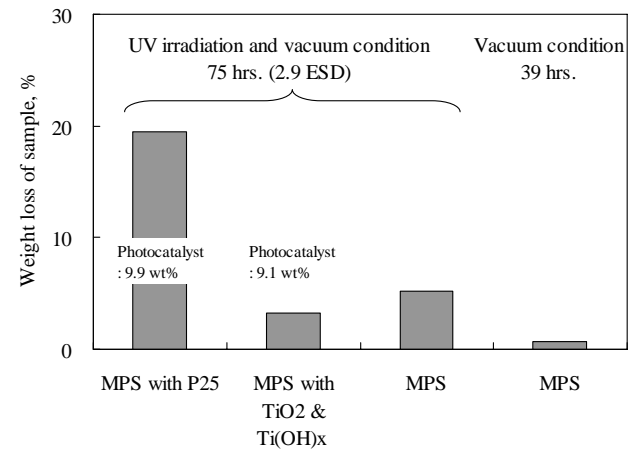

第 8 図 MPS 重量減少率

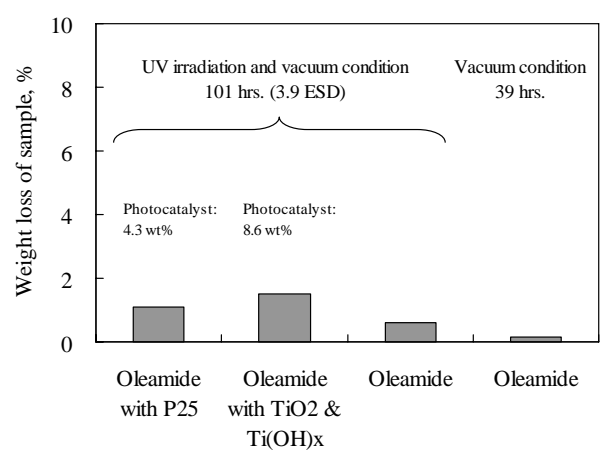

第 9 図 オレアミドの重量減少率

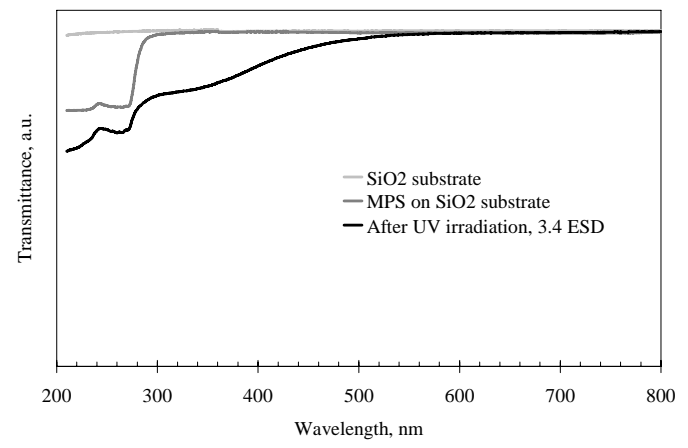

第 10 図 UV 照射前後の MPS の UV/VIS 透過スペクトル

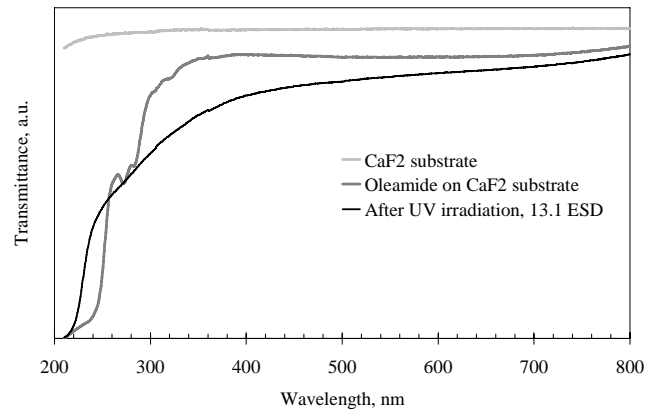

第 11 図 UV 照射前後のオレアミドの UV/VIS 透過スペクトル

4.2 光触媒薄膜 前節では光触媒粒子がコンタミネー ションモデル物質の重量減少に効果があることを確認した. ここでは, 重量減少及び可視光透過率に対する光触媒薄膜 の効果を確認した．モデル物質にはオレアミド及び DEHP 
(標準状態で液体)を用いた。DEHP も「ひので」使用材料か ら放出されるアウトガス成分である. アナターゼ型 $\mathrm{TiO}_{2}$ の 屈折率は $2.6^{9)}$, DEHP は 1.485 であるため, $\mathrm{TiO}_{2} / \mathrm{CaF}_{2}$ 基板 に DEHP を塗布すると DEHP が反射防止膜として作用し, 第 2 図に示す透過率よりも大きくなる現象があった。透過 率変化を指標として光触媒によるコンタミネーション防止 効果を評価するに当たり, このような現象は評価をより困 難にした．そのため，1) モデル物質を塗布した $\mathrm{TiO}_{2} / \mathrm{CaF}_{2}$ 基板，2） $\mathrm{TiO}_{2} / \mathrm{CaF}_{2}$ 基板，3）モデル物質を塗布した $\mathrm{CaF}_{2}$ 基 板，4) $\mathrm{CaF}_{2}$ 基板，の計 4 サンプルを 1 つのシャーレ内に入 れ, 真空中 UV 照射実験を行った. No.1, 3 に関しては重量変 化を測定し, No.2, 4 に関しては UV/VIS 透過スペクトル測定 を行った.モデル物質を塗布していない№.2, 4 の基板には, 隣の基板上のモデル物質からの光分解物や蒸発物に加え, 真空チャンバ自体からのコンタミネーションが入射すると 考えられる.UV 照射による各モデル物質の重量変化を第 12,13 図，透過光強度変化を第 14,15 図に示寸. 第 14,15 図中の波長は「ひので」可視光磁場望遠鏡の観測波長であ る. UV/VIS 分光光度計による透過光強度の測定誤差は土 0.01 である。第 12,13 図より, $\mathrm{TiO}_{2}$ 薄膜上のモデル物質の 重量減少率はモデル物質単体よりも若干上回ったが, 光触 媒粒子に比べると $\mathrm{TiO}_{2}$ 薄膜によるモデル物質の重量減少効 果は少なかった。これは, $\mathrm{TiO}_{2}$ 薄膜と有機物の接触面積が 光触媒粒子の場合よりも小さくなるためと考えられる。一 方, 透過光強度に関しては, 第 14,15 図に示すように, $\mathrm{TiO}_{2} / \mathrm{CaF}_{2}$ 基板では増加傾向を示し, $\mathrm{CaF}_{2}$ 基板では減少傾向 を示した。 また, $\mathrm{TiO}_{2} / \mathrm{CaF}_{2}$ 基板では長波長よりも短波長の 透過光強度のほうが大きくなる傾向を示し, $\mathrm{CaF}_{2}$ 基板では その逆となった. 第 15 図より, いずれの基板においても大 気中で UV を照射しアセトンで洗浄すると元の透過光強度 に戻った. これらの傾向は $\mathrm{TiO}_{2} / \mathrm{SiO}_{2}$ 基板, $\mathrm{SiO}_{2}$ 基板でも同 様であった. 光触媒をコーティングしていない $\mathrm{CaF}_{2}, \mathrm{SiO}_{2}$ 基板にはコンタミネーションが付着し, 時間の経過ととも に短波長側の透過光強度が徐々に低下している ${ }^{2)}$ と推測さ れる. $\mathrm{TiO}_{2} / \mathrm{CaF}_{2}, \mathrm{TiO}_{2} / \mathrm{SiO}_{2}$ 基板の透過光強度増加の原因と しては，1) ゾル・ゲル法で合成した $\mathrm{TiO}_{2}$ 薄膜内に原料の有 機物が含有され, 真空中 UV 照射により分解除去された,

2) 低屈折率の付着物が反射防止膜として作用した, が挙げ られる。

$\mathrm{TiO}_{2}$ 薄膜内に残留した原料の有機物が原因であるならば, アセトン洗浄前後で透過光強度は変化しないと考えられる が, 第 15 図よりほぼ元の状態に戻ったためこれが主要因と は考え難い.

次に反射防止膜効果について考察する. DEHP の屈折率 を 1.485, $\mathrm{TiO}_{2}$ 薄膜を 2.6, 付着物の光吸収率をゼロと仮定 して反射防止膜効果 ${ }^{21)}$ を計算すると第 16 図の通りとなる.
第 16 図では波長が短いほど透過光強度が高くなる傾向を 示しており, 第 14,15 図の $\mathrm{TiO}_{2} / \mathrm{CaF}_{2}$ 基板の傾向と一致して いる. また，付着物が除去されると透過光強度は 1 となる が, 第 15 図よりアセトン洗浄後に透過光強度がほぼ元の状 態に戻っており，これについても傾向が一致している。さ らに，第 13 図に示すように， $\mathrm{TiO}_{2} / \mathrm{CaF}_{2}$ 基板上の $\mathrm{DEHP}$ は 完全に分解されずに約 $5 \mathrm{wt} \%$ 残留した. したがって, 真空 中で $\mathrm{TiO}_{2}$ 薄膜は付着物を完全に分解できず，一部残留して しまったものが反射防止膜として作用した可能性がある.

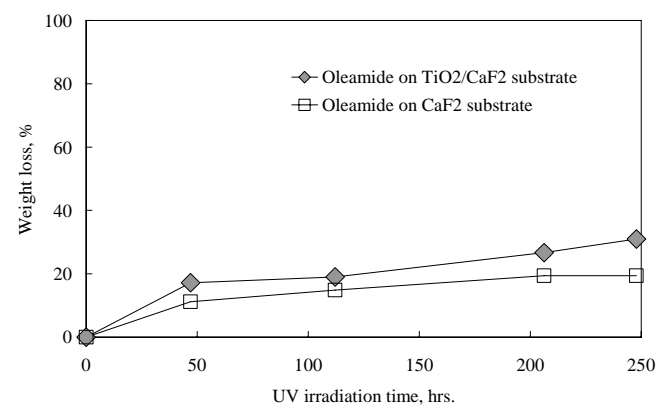

第12図 オレアミドの重量変化

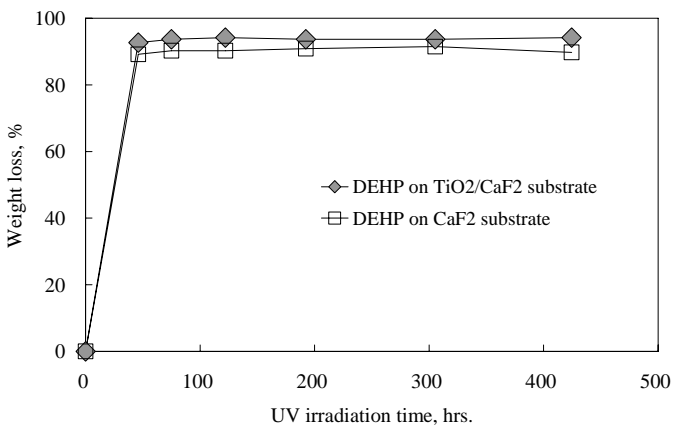

第 13 図 DEHP の重量変化
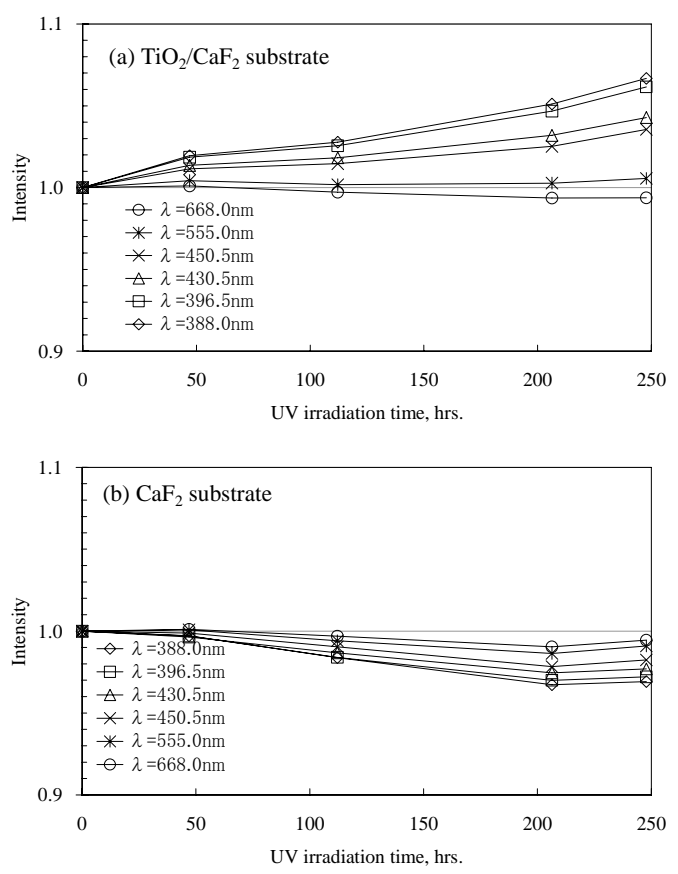

第 14 図 オレアミド周辺に置いた基板の透過光強度変化 

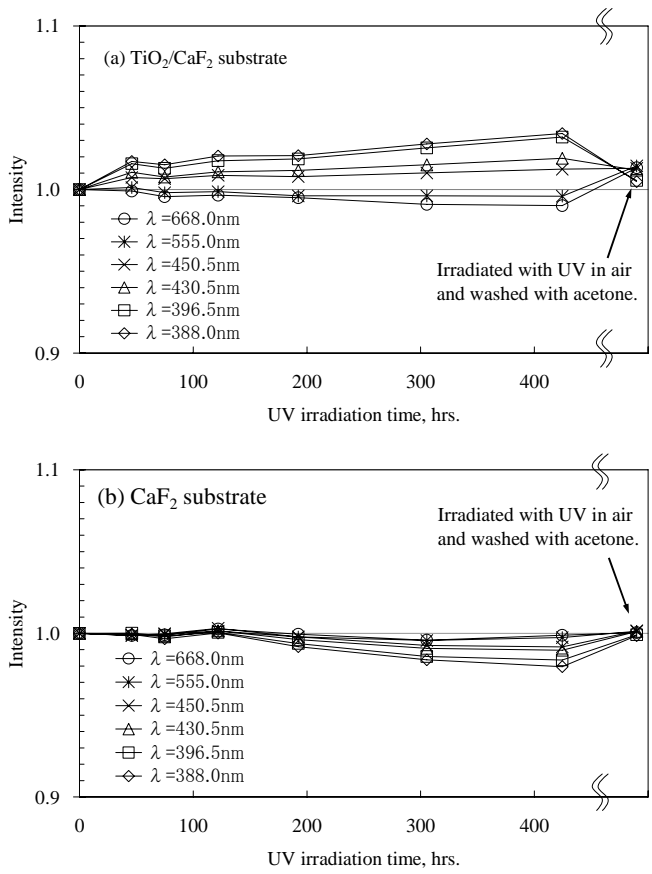

第 15 図 DEHP 周辺に置いた基板の透過光強度変化

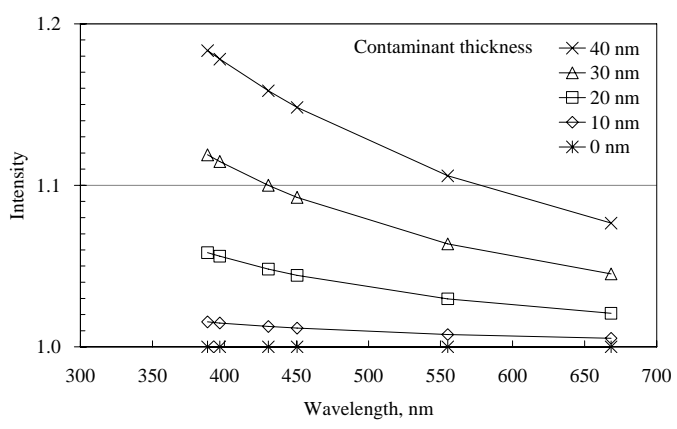

第 16 図付着物の反射防止膜効果（計算值）

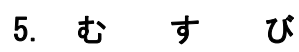

$\mathrm{TiO}_{2}$ 粒子及び $\mathrm{TiO}_{2}$ 薄膜は，真空中 UV 照射下でのコンタ ミネーションモデル物質(スクアレン, MPS, オレアミド, DEHP)の重量減少に効果があることがわかった。また，原 因の特定には至っていないが， $\mathrm{TiO}_{2}$ 薄膜サンプルの透過光 強度は時間の経過とともに増加していく傾向があることが わかった。

本研究では, 熱制御材や光学系への光触媒の適用を目指 しているため, 第一段階としてコンタミネーション付着量 と光学的な変化に焦点を当てて実験を行った. 今回の実験 で観察された現象の解明には, 直接的な分析（表面分析, 脱離物の分析）も併用していく必要がある. また, 第 2 図 に示すように, 可視光での $\mathrm{TiO}_{2}$ 薄膜サンプルの透過率は $\mathrm{CaF}_{2}$ 基板より最大 $30 \%$ 低いものであった. $\mathrm{TiO}_{2}$ の熱処理方 法を改善するとともに，コーティング厚をさらに薄くする 必要がある。宇宙環境への適用を目指寸ためには, 放射線 による劣化特性や, 熱サイクルによる基板への光触媒薄膜
の密着性なども評価する必要がある.

本研究は（財）日本宇宙フォーラムが推進している「宇 宙環境利用に関する地上研究公募」プロジェクトの一環と して行ったものである，本実験に当たり，国立天文台の常 田佐久教授に太陽観測衛星「ひので」のコンタミネーショ ン物質に関する情報をご提供頂いた，著者一同梁く感謝し ている.

\section{参 考 文 献}

1) Mauldin, L. E., III and Chu, W. P.: Optical Degradation Due to Contamination on the SAGE/SAGE II Spacecraft Instruments, Proc. SPIE, Vol. 338, 1982, pp.58-64.

2) Tribble, A. C., Boyadjian, B., Davis, J., Haffner, J. and McCullough, E.: Contamination Control Engineering Design Guidelines for the Aerospace Community, NASA CR-4740, 1996.

3) Leschly, K., Taylor, D. M., Jenkins, T. K. and Barengoltz, J. B.: Strategy for Contamination Control to Improve Wide-Field Planetary Camera Far-Ultraviolet Performance, Proc. SPIE, Vol. 1329, 1990, pp. 42-57.

4) Du, Y. and Rabini, J.: The Measure of $\mathrm{TiO}_{2}$ Photocatalytic Efficiency and the Comparison of Different Photocatalytic Titania, J. Phys. Chem. B, 107 (2003), pp.11970-11978.

5) 佐々木進, 賀谷信幸, 佐川永一：Space Flyer Unit (SFU)で計測された ガス環境, 宇宙科学研究所報告第 97 号, 1997.

6) Hayashi, T., Urayama, F., Takeda, N., Yoshikawa, J. and Baba, N.: Experimental Approach for Modeling on External Molecular Contaminants Behaviors, 54 ${ }^{\text {th }}$ IAC, 2003.

7) 浦山文隆, 渡辺吉男, 矢野敬一, 馬場尚子 : ひので可視光望遠鏡にお ける軌道上コンタミネーションの影響評価，宇宙技術, 6 (2007), pp.25-30.

8) Schmidl, W., Alred, J., Mikatarian, R., Soares, C., Miles, E., Howorth, L., Mishina, L. and Murtazin, M.: U.S.LAB Condensate Vent Experiment and Analysis”, 9th International Symposium on Materials in a Space Environment, 2003.

9) Diebold, U.: The Surface Science of Titanium dioxide, Surf. Sci. Rep., 48 (2003), pp.53-229.

10）浦山文隆, 古川睦久, 小澤清, 土佐正弘, 木村秀夫: 真空環境下での 光触媒による有機物分解の試み, 第 50 回宇宙科学技術連合講演会講 演集, 2006, pp.1279-1282.

11) 西本清一, 大谷文章, 坂本章, 鍵谷勤: 硫酸チタン(IV)から調製した 酸化チタン(IV)の光触媒活性, 日本化学会誌, 2 (1984), pp.246-252.

12) Takahashi, Y. and Matsuoka, Y.: Dip-Coating of $\mathrm{TiO}_{2}$ Film Using a Sol Derived from Ti(O-i-Pr) $)_{4}$-diethanolamine- $\mathrm{H}_{2} \mathrm{O}-\mathrm{i}$-PrOH System, J. Mater. Sci., 23 (1988), pp.2259-2266.

13) Rugg, F. M., Smith, J. J. and Bacon R. C.: Infrared Spectrophotometric Studies on Polyethylene, J. Polymer Science, 13 (1954), pp.535-547.

14) Yeo, H. C. H. and Shibamoto, T.: Formation of Formaldehyde and Malonaldehyde by Photooxidation of Squalene, LIPIDS, 27, 1 (1992), pp.50-53.

15) Brinkley, D. and Engel, T.: Photocatalytic Dehydrogenation of 2-Propanol on $\mathrm{TiO}_{2}(110)$, J. Phys. Chem. B, 102 (1998), pp.7596-7605.

16) Iseda, K.: Oxygen Effect on Photocatalytic Reaction of Ethanol over Some Titanium Dioxide Photocatalysts, Bull. Chem. Soc. Jpn., 64 (1991), pp.1160-1166.

17) Hoffmann, M. R., Martin, S. T., Choi, W. and Bahnemann, D. W.: Environmental Applications of Semiconductor Photocatalysis, Chem. Rev., 95 (1995), pp.69-96.

18) Siegel, S. and Stewart, T.: Vacuum-Ultraviolet Photolysis of Polydimethylsiloxane, J. Phys. Chem., 73, 4 (1969), pp.823-828.

19) Hall, D. F. and Stewart, T. B.: Photo-Enhanced Spacecraft Contamination Deposition, AIAA-85-0953, 1985, pp.1-9.

20) Dever, J. A.: In Flight-Vehicle Materials, Structures, and Dynamics, New

York, 1994, Vol. 2, Section 5, pp. 426.

21) 金原寿郎編：基礎物理学, 裳華房, 1963. 